Chirurgia (2018) 113: 857-866

No. 6, November - December

Copyright@ Celsius

http://dx.doi.org/10.21614/chirurgia.113.6.857

\title{
Gastric Cancer, Hemophilia A and Angiodysplasia - An Unreported Association with Clinical Implications in a Patient with Digestive Hemorrhage
}

\author{
Alexandru Martiniuc ${ }^{1,7}$, Mugur Grasu ${ }^{2,7}$, Radu Dumitru ${ }^{2,7}$, Mihai Toma ${ }^{2}$, Gina Rusu' ${ }^{2}$, Gratiela Manga ${ }^{3}$, \\ Ecaterina Scărlătescu' ${ }^{3}$, Bogdan Cotruță ${ }^{4}$, Melen Brânză ${ }^{5}$, Răzvan Stoia ${ }^{5}$, Vlad Herlea ${ }^{6,8}$, Traian Dumitrascu ${ }^{1,7}$ \\ "Dan Setlacec" Center of General Surgery and Liver Transplantation, Fundeni Clinical Institute, Bucharest, Romania \\ 2Department of Medical Imaging and Interventional Radiology, Fundeni Clinical Institute, Bucharest, Romania \\ ${ }^{3}$ Department of Anesthesiology and Intensive Care Medicine, Fundeni Clinical Institute, Bucharest, Romania \\ ${ }^{4}$ Department of Gastroenterology, Fundeni Clinical Institute, Bucharest, Romania \\ ${ }^{5}$ Department of Hematology, Fundeni Clinical Institute, Bucharest, Romania \\ ${ }^{6}$ Department of Pathology, Fundeni Clinical Institute, Bucharest, Romania \\ ${ }^{7}$ "Carol Davila" University of Medicine and Pharmacy, Bucharest, Romania \\ ${ }^{8}$ "Titu Maiorescu" University, Bucharest, Romania
}

Corresponding author:

Traian Dumitrascu, MD, PhD

"Carol Davila" University of Medicine and Pharmacy, "Dan Setlacec" Center of General Surgery and Liver Transplantation, Fundeni Clinical Institute, Fundeni Street no 258, 022328, Bucharest, Romania E-mail: traian.dumitrascu@umfcd.ro

Received: 31.12 .2017 Accepted: 17.02 .2018

\section{Rezumat \\ Adenocarcinom gastric, hemofilie A și angiodisplazie - o asociere cu implicatii clinice la un pacient cu hemoragie digestivă}

Introducere: Cancerul gastric este rareori cauza unei hemoragii digestive superioare acute. Comorbiditățile pacientului pot avea un efect negativ atât asupra rezultatelor imediate cât şi asupra celor tardive, după rezecția chirurgicală a unui cancer gastric. Asocierea cancerului gastric cu hemofilia A şi angiodisplazie nu a mai fost raportată până în prezent în literatura de specialitate, iar impactul acestei asocieri asupra rezultatelor postoperatorii este necunoscut. Prezentarea cazului: Un bărbat de 49 de ani, cunoscut cu hemofilie A, se prezintă cu hemoragie digestivă superioară şi anemie secundară severă, fiind diagnosticat cu adenocarcinom gastric. Se practică gastrectomie totală cu splenectomie şi limfodisecție D2. Evoluția postoperatorie a fost complicată de apariția unui nou episod de hemoragie digestivă datorat prezenței leziunior angiodisplazice la nivelul cecului şi jejunului; episodul de hemoragie digestivă a fost tratat fde această dată, cu success, prin embolizare radiologică. In perioada pre şi postoperatorie pacientul a primit factor VIII, dar a dezvoltat auto-anticorpi împotriva factorului VIII. Astfel, administrarea de factor VIII a fost întreruptă şi înlocuită cu FEIBA ("factor 
eight inhibitor bypassing activity"). Pacientul a fost externat în ziua 41 postoperator, fără semne de sângerare.

Concluzii: Din cunoştiințele noastre, acesta reprezintă primul caz raportat de asociere cancer gastric - hemofilie A - angiodisplazie. Toate aceste patologii amintite pot determina hemoragie digestivă şi pot pune probleme extrem de dificile în ceea ce priveşte diagnosticul şi tratamentul lor. Abordarea multidisciplinară (hematolog, chirurg, anestezist, endoscopist, radiolog intervențional) este obligatorie pentru a obține un diagnostic şi un tratament corect pentru aceşti pacienți.

Cuvinte cheie: hemoragie digestivă, cancer gastric, hemofilie A, angiodisplazie, rezultate postoperatorii

\section{Abstract}

Introduction: Gastric cancer is a rare cause of upper digestive hemorrhage. Associated co-morbidities may have a detrimental effect on both early and long-term outcomes after surgery for gastric cancer. Association of gastric adenocarcinoma with hemophilia A and angiodysplasia was not previously reported, and the impact on postoperative outcome is not known.

Case Report: A 49-year-old male with inherited hemophilia A presented with upper digestive hemorrhage and severe anemia, and was diagnosed with gastric carcinoma. The patient underwent total gastrectomy with splenectomy and D2 lymph nodes dissection. The postoperative outcome was complicated by digestive hemorrhage due to the presence of lesions of angiodysplasia of the cecum and jejunum that were successfully treated with coils mounted by the interventional radiologic approach. During the pre and postoperative periods, the patient received human coagulation factor VIII and developed auto-antibodies against factor VIII. Thus, human coagulation factor VIII administration was stopped and replaced with factor eight inhibitor bypassing activity (FEIBA). The patient was discharged at home on postoperative day 41 , without any signs of bleeding.

Conclusion: To the best of our knowledge, this is the first reported association of gastric adenocarcinoma, hemophilia A and angiodysplasia. All these lesions may lead to digestive hemorrhage and can pose very difficult problems of decision for diagnosis and therapy. A multidisciplinary approach including hematologist, surgeon, anesthesiologist, endoscopist and the interventional radiologist is mandatory to have a proper diagnosis and management for these patients.

Key words: digestive hemorrhage, gastric cancer, hemophilia A, angiodysplasia, outcome

\section{Introduction}

Gastric cancer is an important healthcare problem worldwide albeit trends in mortality were significantly downward in all countries, including Romania (1). However, gastric cancer is still a high burden in some regions, including East Europe (1).

Treatment of gastric cancer is multimodal, and it is tailored to stage of disease (2). Curative-intent surgery for gastric cancer implies total or subtotal gastrectomy with D2 lymph nodes dissection, with improved oncological results, compared with D1 lymph nodes dissection (3).

Associated co-morbidities may have a detrimental effect on both early and longterm outcomes after surgery for gastric cancer $(4,5)$.

Hereby it is presented the case of a patient diagnosed with gastric cancer and associated co-morbidities such as hemophilia A and angiodysplasia. The clinical implications and management are discussed. 


\section{Case Report}

A 49-year-old male, ex-smoker, present in a Gastroenterology Department with melena and influenced general status. Physical examination revealed pallor, tachycardia (100 beats per minute) and hypotension (systolic blood pressure $90 \mathrm{~mm} \mathrm{Hg}$ and diastolic blood pressure $60 \mathrm{~mm} \mathrm{Hg}$ ). The rectal examination confirmed melena.

His medical history included inherited hemophilia A, mild form (diagnosed 20 years before due to epistaxis, ecchymosis and macroscopic hematuria, with factor VIII serum level at diagnosis $12.4 \%$ ) and previous surgery (resection for spinal cord ependymoma complicated with postoperative hemorrhage, 30 years before). The patients presented two years before an episode of melena spontaneously remitted and, at that time, the upper and inferior digestive endoscopy were negative.

At present, the blood tests revealed severe anemia (hemoglobin serum level of $5 \mathrm{~g} / \mathrm{dl}$ ) and no other abnormalities. Factor VIII serum level was 59\%. Furthermore, the viral markers (hepatitis B and $\mathrm{C}$ viruses) and tumor markers (CA 19-9, carcinoembryonic antigen and alphafetoprotein) were negative.

Upper digestive endoscopy revealed an infiltrated wall of the mid portion of the stomach, with friable mucosa, thickened folds and small erosions with hemorrhage, suggesting a malignant etiology (Fig. 1). However, repeated biopsies did not identify any malignant cells, but only signs of chronic gastritis.

Contrast-enhanced computed tomography revealed a thickened mid portion of the stomach, with the disappearance of folds and a reduced lumen at this level (Fig. 2). No other abnormalities were observed in loco-regional lymph nodes, liver, peritoneum or lungs.

Although the biopsies were negative, based on the clinical signs, endoscopic and computed tomography appearances, a clinical diagnosis of gastric linitis was presumed, and the patient was proposed for surgery.

After a preoperative preparation (blood transfusions with hemoglobin serum level of $7.3 \mathrm{~g} / \mathrm{dl}$ and administration of human coagulation factor VIII - IMMUNATE ${ }$, with factor VIII serum level of $136 \%$ at the time of surgery), the patient was referred to surgery in July 2016.

At laparotomy, it was observed diffuse thickening of the mid portion of the stomach invading the spleen, highly suggestive of gastric linitis plastica (Fig. 3). Furthermore, no metastases in loco-regional lymph nodes or

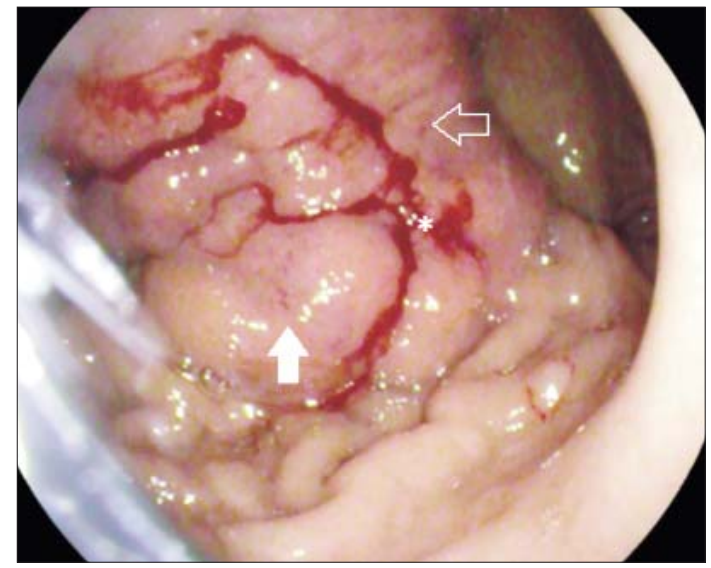

Figure 1. Upper digestive endoscopy revealing an infiltrated wall of the mid portion of the stomach (white open arrow), with friable mucosa, thickened folds (white filled arrow) and small erosions with hemorrhage $\left({ }^{*}\right)$, suggesting a malignant etiology.

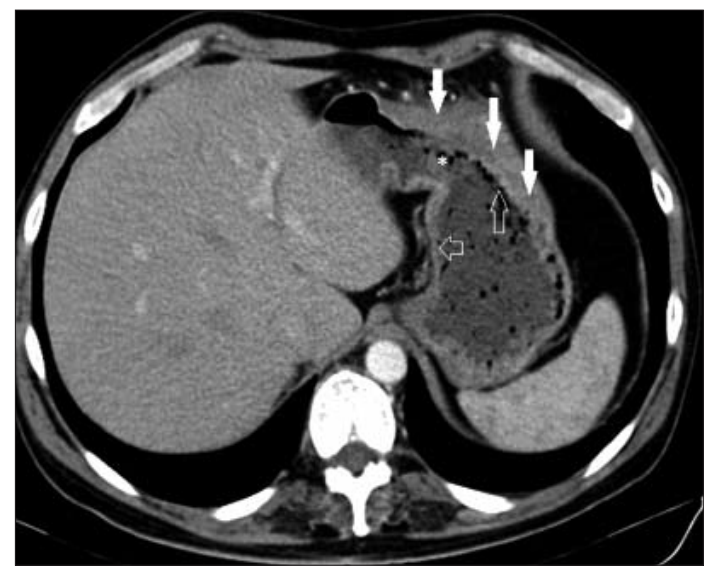

Figure 2. Axial plane contrast-enhanced computed tomography revealing a thickened mid portion of the stomach (white open arrows), with disappearance of folds (white filled arrows) and reduced lumen ( $\left.{ }^{*}\right)$. 


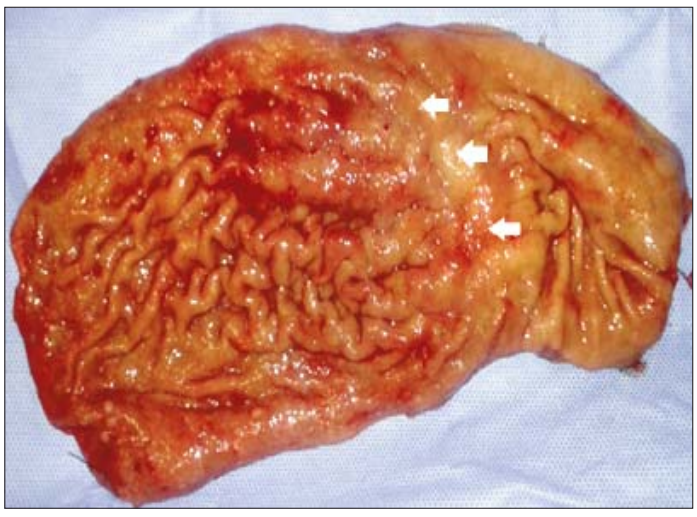

Figure 3. Operative specimen of total gastrectomy with diffuse thickening of the mid portion of the stomach (white filled arrows)

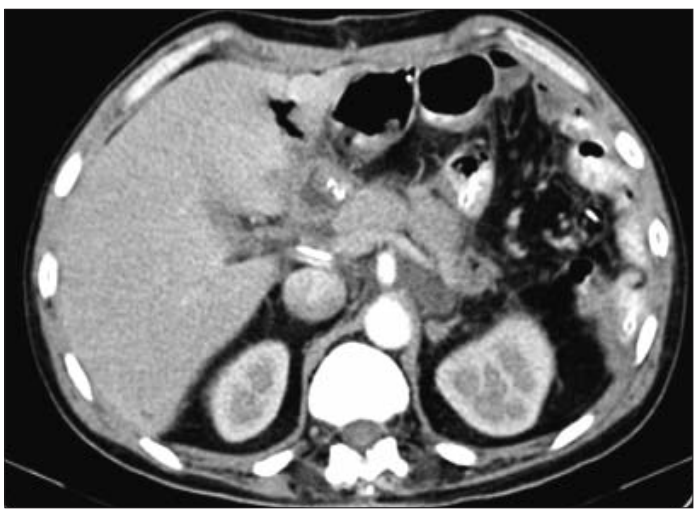

Figure 4. Axial plane contrast-enhanced computed tomography on postoperative day 7 revealing no abnormalities liver were observed. However, two small nodules of less than $5 \mathrm{~mm}$ were observed at the level of great and lesser omentum. A frozen section examination of both nodules revealed chronic inflammation, without malignant cells.

Consequently, a total gastrectomy with omentectomy, bursectomy, splenectomy and D2 lymph nodes dissection was performed. The digestive reconstruction was made with a Roux-en-Y anastomosis. A nasojejunal feeding tube was mounted intraoperatively.

The postoperative evolution appears to be without any significant events during the first 6 days (the patient was in good condition, with no fever, with oral tolerance, a hemoglobin serum level of $9 \mathrm{~g} / \mathrm{dl}$ and factor VIII serum level of $92 \%$, with IMMUNATE ${ }^{\circledR}$ administration).

On postoperative day 7 the patient presented fever $\left(38.7^{\circ} \mathrm{C}\right)$ and in one drainage tube an output of $50 \mathrm{ml}$ highly suggestive for pancreatic fistula (confirmed afterward by very high levels of amylase and lipase in the drainage output). A contrast-enhanced computed tomography of the abdomen and pelvis did not reveal any abnormalities (Fig. 4). Blood tests revealed leukocytosis (12 000 per L) and hemocultures were positive for Klebsiella pneumoniae. Intravenous antibiotics were introduced according to the antibiogram.

After that, the postoperative outcome appears to be good with no fever and with oral tolerance; the pancreatic fistula was closed, and the last drain was removed. A radiological examination with oral gastrografin performed on postoperative day 8 revealed a patent esojejunal anastomosis, without extravasations of contrast (Fig. 5).

The patient was prepared to be transferred to the Department of Hematology for hemophilia treatment.

On postoperative day 12 , the patient presented two episodes of lypotimia without any signs of external hemorrhage but with hemoglobin serum level of $5.8 \mathrm{~g} / \mathrm{dl}$, while factor VIII serum level was 98\% with IMMUNATE $^{\circledR}$ administration. Contrast-enhanced computed

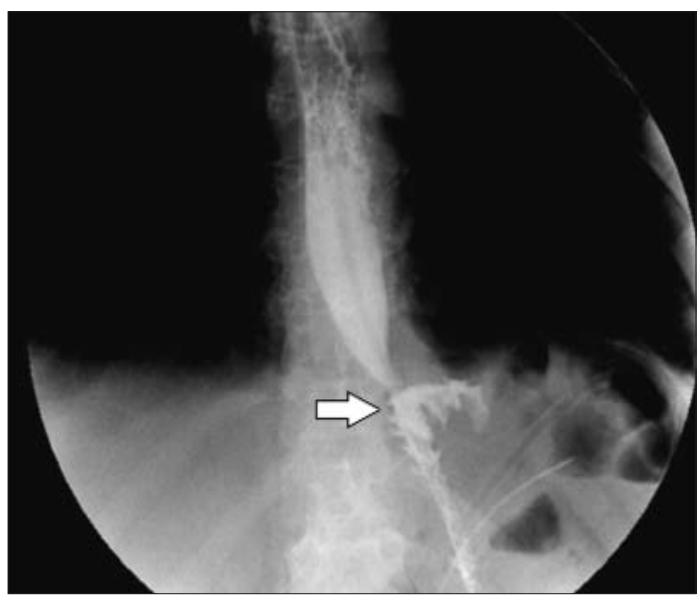

Figure 5. Radiological examination with oral gastrografin performed on postoperative day 8 revealing a patent eso-jejunal anastomosis (white filled arrow), without extravasations of contrast 


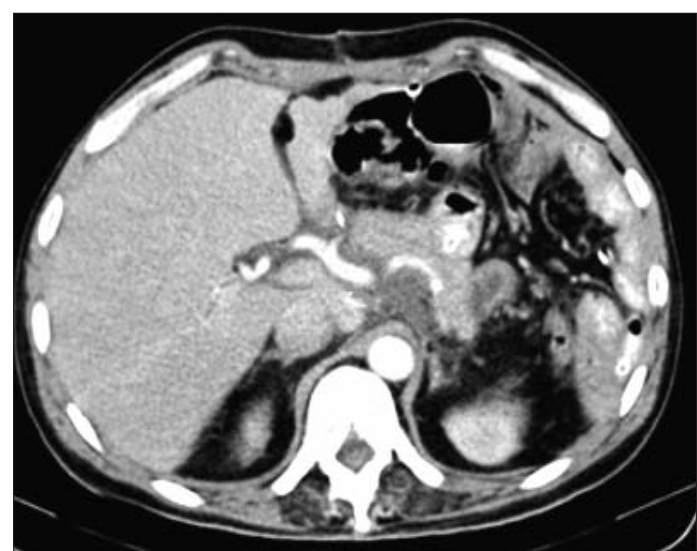

Figure 6. Axial plane contrast-enhanced computed tomography on postoperative day 12 revealing no active bleeding, hematoma or collections

tomography did not show any signs of bleeding. No hematoma or collections were observed (Fig. 6). Blood transfusions were performed, but the hemoglobin serum level did not increase. Upper digestive endoscopy and angiography were not available. Due to the clinical deterioration of the patient status (tachycardia, hypotension), it was decided to return the patient to the operative room for surgical re-exploration.

At re-laparotomy, no blood or collection was detected in the abdominal cavity. Eso-jejunal, duodenal stump and entero-enteral anasto- moses were explored, but no bleeding sources were observed albeit the presence of blood in the small bowel was noticed.

After re-exploration, the patient was hemodynamically stable (under blood transfusion and IMMUNATE ${ }^{\circledR}$ administration), without any signs of digestive hemorrhage.

However, on postoperative day 16 , the patient presented a decrease in hemoglobin serum level with $2 \mathrm{~g} / \mathrm{dl}$, with hematochezia, and an angiography was performed. Thus, it was revealed the presence of an angiodysplasia lesion at the level of the cecum (Fig. $7 \mathrm{~A}$ ), with active bleeding, and a coil was inserted (Fig. 7 B).

Furthermore, the patient was hemodynamically stable, without any clinical or bioumoral signs of hemorrhage, but developed fever. Contrast-enhanced computed tomography revealed no intra-abdominal collections but inflammatory (ischemic?) modification of the cecum wall (Fig. 8). Cultures from blood, urine and drainage tubes were negative.

The postoperative evolution was relatively stable untill postoperative day 26 when the patient developed another episode of digestive hemorrhage with hematemesis. Hemoglobin serum level dropped from $9.5 \mathrm{~g} / \mathrm{dl}$ to $7.4 \mathrm{~g} / \mathrm{dl}$ and factor VIII serum level was $47 \%$ with
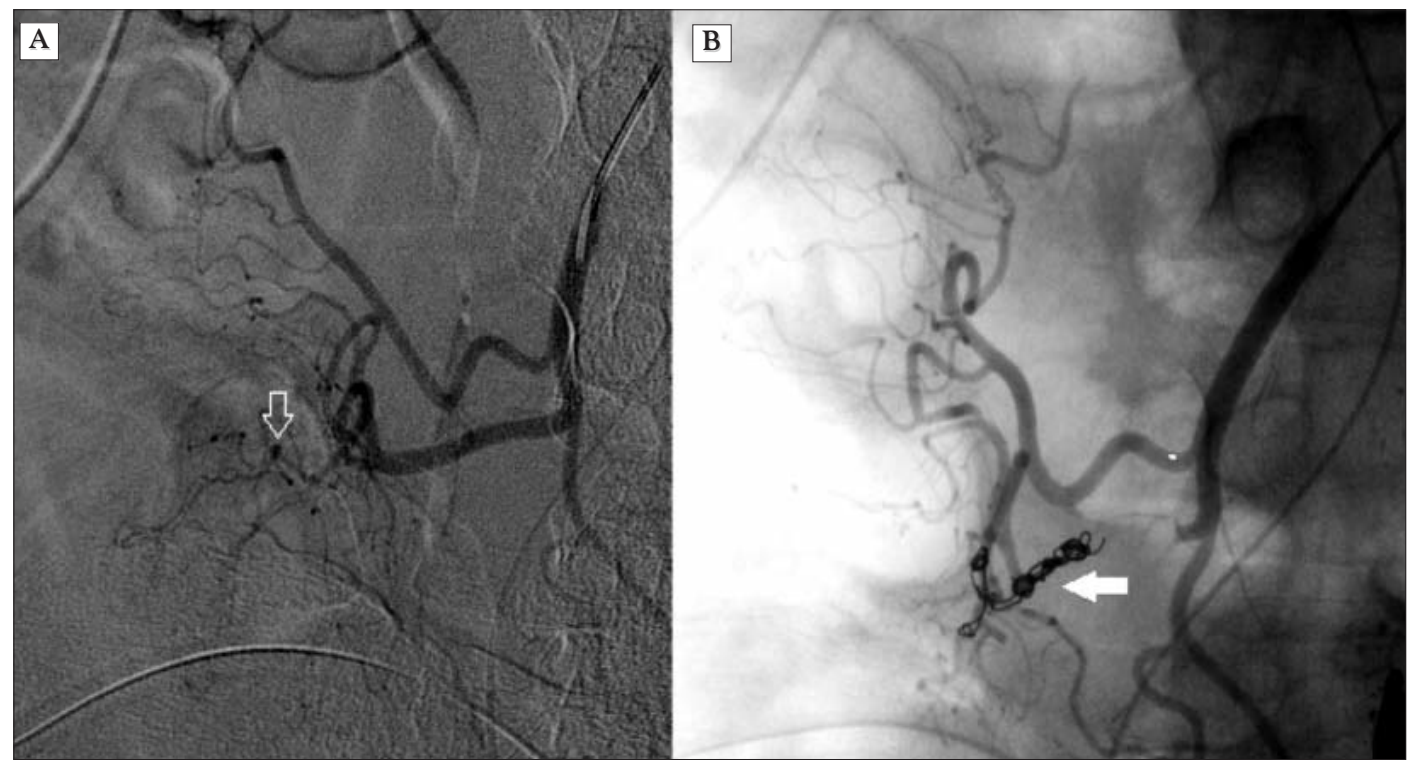

Figure 7. Digital subtraction angiography revealing angiodisplasia of cecum (a) with active bleeding from a small branch of ileo-cecal artery (white open arrow) and (b) after coils mount (white filled arrow) 


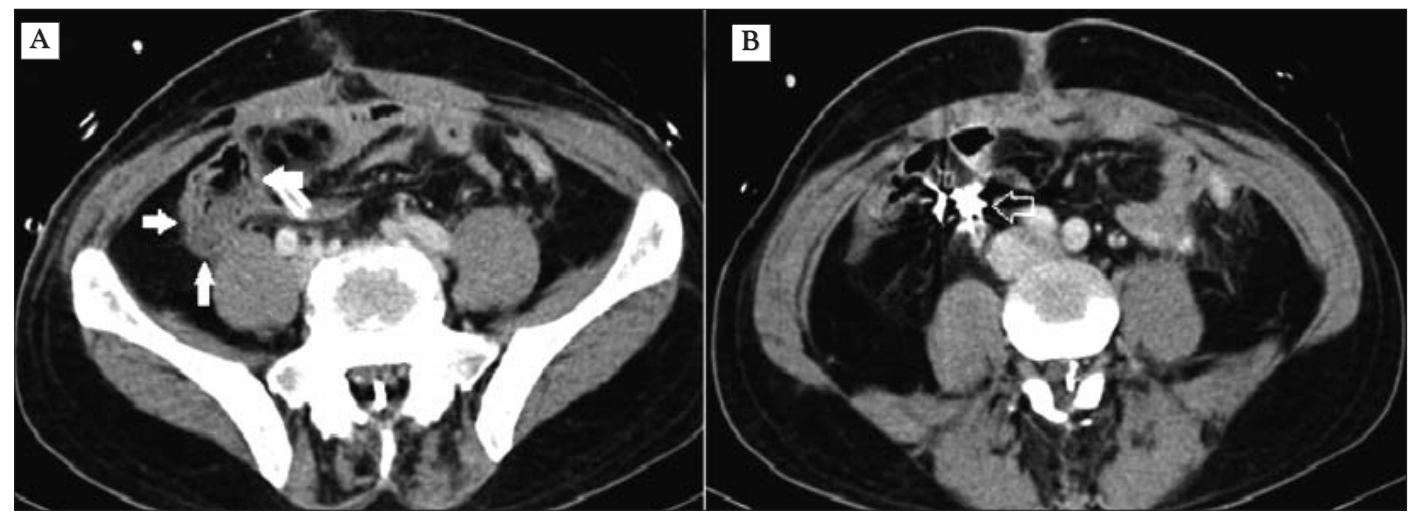

Figure 8. Axial plane contrast-enhanced computed tomography revealing $(A)$ inflammatory modifications of the cecum walls (white filled arrows) and (B) the presence of coils (white open arrow)

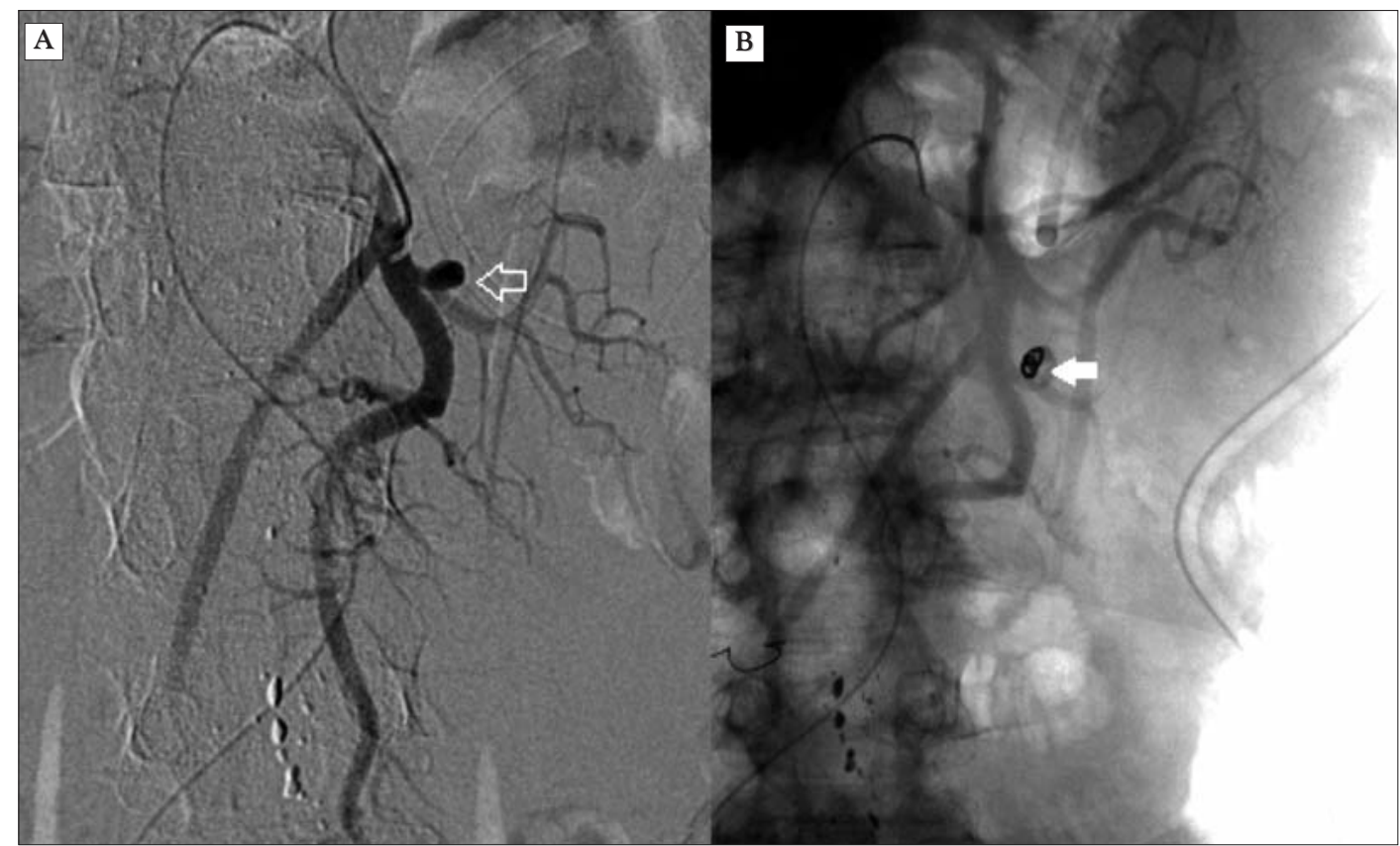

Figure 9. Digital subtraction angiography revealing angiodysplasia of jejunum (A) with active bleeding from a small branch of first jejunal artery (white open arrow) and (B) after coils mount (white filled arrow)

IMMUNATE $®$ administration. Blood transfusions were performed and upper digestive endoscopy revealed the presence of fresh blood in jejunum, without source identification. Furthermore, an angiography was performed revealing jejunal angiodysplasia with active bleeding (Fig. 9, A). A coil was mounted, and the bleeding stopped thereafter (Fig. 9, B).

On postoperative day 35 it was observed the formation of auto-antibodies against factor VIII. The titre of inhibitors was 16 Bethesda units while factor VIII serum level was $47 \%$.
The IMMUNATE ${ }^{\circledR}$ administration was stopped and replaced with factor eight inhibitor bypassing activity (FEIBA).

Afterwards, the postoperative outcome was uneventful, and the patient was discharged on postoperative day 41, hemodynamically stable, without fever and with good oral tolerance. Contrast-enhanced computed tomography performed on postoperative day 62 revealed no abnormalities (Fig. 10), while the hemoglobin serum level was $10.7 \mathrm{~g} / \mathrm{dl}$.

The final pathological examination revealed 


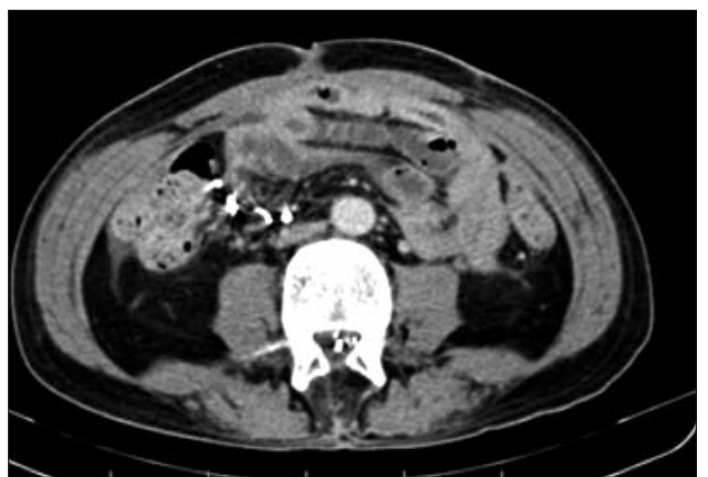

Figure 10. Axial plane contrast-enhanced computed tomography on postoperative day 62 revealing no abnormalities

undifferentiated diffuse infiltrative carcinoma with signet ring cell, with one positive lymph node out of 64 . Unfortunately, the two omental nodules presented malignant cells. Thus, the patient was assessed as stage IV (pT3, pN1, $\mathrm{pM} 1$ peritoneal). The patient died at a later time probably due to peritoneal recurrence.

\section{Discussion}

Gastric cancer represents less than $2 \%$ of cases of upper gastrointestinal bleeding (6). Presence of upper digestive hemorrhage in a patient with gastric cancer did not preclude an oncologically safe gastrectomy but was associated with increased rates of postoperative complications (7). Furthermore, although the emergency presentation of gastric cancer (including upper digestive hemorrhage) is rare(8), however, it was associated with poor prognosis due to advanced stage at diagnosis, low resectability rates and high rates of recurrence after curative-intent surgery $(8,9)$.

Linitis plastica is a rare subset of gastric adenocarcinoma (3.2\% of patients) with significantly worse prognosis (10). To date, it is not clear if the poor prognosis of linitis plastica is related to its advanced stage at diagnosis or it is a matter of aggressive tumor biology (11).

The diagnosis of linitis plastica is challenging because tumor infiltration is submucosal and biopsies are usually negative (12). Typical endoscopic findings in linitis plastica include fold hypertrophy, sclerosis, nodularity and thickening (12), as it was the case in the reported patient. The most common findings in linitis plastica at computed tomography are represented by wall thickening $(91.7 \%)$, complete disappearance of folds and enhancement of the entire wall (13), as it was the case in above-presented case.

Recently it was shown that with optimal surgery (i.e., negative resection margins and D2 lymph nodes dissection) there are no significant differences of overall survivals between patients with linitis plastica and patients with non-linitis plastica gastric adenocarcinoma (11).

Peritoneal dissemination is a common appearance in linitis plastica (up to $41 \%$ of patients) and, for these patients, gastrectomy appears to be of no use (14). It is worth to mention however that intraoperative frozen section analyses in gastric cancer has no 100\% accuracy (15). Thus, peritoneal metastases can be misdiagnosed as fat necrosis, benign cysts, dystrophic calcifications, fibrosis, hyalinized nodule, acute and chronic inflammation, and foreign body granulomas (16), particularly for small lesions and undifferentiated tumors (17), as it was the case in the presented patient. The chance to detect peritoneal metastases in patients with gastric adenocarcinoma is higher when immunocytochemical methods are used, compared with routine cytopatology (18). Nevertheless, without any pathological proof of peritoneal dissemination, a curative-intent surgery should be performed, as it was the case in the reported patient. However, in our patient the final pathological examination revealed the presence of peritoneal metastases. Thus, the resection was not curative.

Hemophilia A is an X-chromosomal recessive disorder caused by the deficiency or lack of factor VIII and manifests with prolonged and excessive bleeding (19). Hemophilia A occurs in one out of 5000 males and accounts for $80 \%$ of hemophilic cases (19).

Hemarthrosis is the most common hemorrhagic symptom in adults with hemophilia A, but excessive postoperative bleeding is not uncommon in these patients (19).

Upper gastrointestinal bleeding occurs in 
up to $25 \%$ of patients with hemophilia but is often linked to the use of non-steroidal antiinflammatory drugs (20).

Hemorrhage severity in hemophilia A correlates with factor VIII deficiency level. Administration of recombinant factor VIII replacement is the treatment of choice for acute bleeding or to prevent bleeding in anticipation of surgery in hemophilia A, and for severe bleeding, it is desirable to achieve $100 \%$ factor VIII level (19), as it was the case in our patient.

It is worth to mention that about $30 \%$ of patients with severe hemophilia A will develop alloantibodies against administered factor VIII (19), a situation associated with increased morbidity rates, particularly bleeding complications (21).

The incidence of malignancies in patients with hemophilia is higher, compared with general population, but most patients have virus-related cancers $(22-24)$, because prevalence of hepatitis B, C and human immunodeficiency virus infection is higher, compared with the general population (23). Thus, hepatocellular carcinoma, leukemia and lymphoma are the most frequent types of cancers in patients with hemophilia $(23,24)$.

Association of inherited hemophilia A with gastric cancer was previously described in only two patients $(25,26)$.

Increased bleeding tendency should raise suspicion of underlying malignancy in an adult patient with hemophilia (22). Radical surgery and other forms of oncological therapy are not contraindicated in patients with hemophilia and malignancies (22). However, surgery of malignant tumors in patients with hemophilia is associated with increased risk of postoperative complications, including bleeding, despite proper replacement therapy (27). Nevertheless, it appears that associated hemophilia does not have a detrimental effect on long-term prognosis of treated malignancies (23).

Acquired hemophilia A is characterized by the formation of auto-antibodies against factor VIII, and is commonly associated with postoperative or iatrogenic bleeding (28). The mortality rate of bleeding is significantly higher for acquired hemophilia, compared with inherited hemophilia (28).

A recent review identified 105 patients in whom factor VIII auto-antibodies developed after surgery for cancer, and $43 \%$ of patients have had hematological malignancies(28). Furthermore, from the group of patients with solid malignancies, prostate, lung and colon were the most frequent cancers $(25.3 \%, 15.8 \%$, and $9.5 \%$, respectively)(28).

Treatment of patients with hemophilia and factor inhibitors aims to eradicate the inhibitor by immune tolerance induction (29). For bleeding episodes, factor eight inhibitor bypassing activity (FEIBA), an activated prothrombin complex concentrate and activated recombinant factor VII are the only available drugs (21).

The above-presented patient with inherited hemophilia A developed after gastrectomy autoantibodies against factor VIII, successfully treated with FEIBA. Acquired hemophilia A was previously described in only five patients with gastric cancer $(27,30-33)$, but none with concomitant inherited hemophilia A.

Angiodysplasia is a pathological communication between dilated mucosal capillaries and submucosal veins (34), and is the most common vascular lesion of the gastrointestinal tract and an important cause of digestive hemorrhage (34). The main locations for angiodysplasia are cecum, ascending colon (80\%) and jejunum (15\%)(34).

The diagnosis of angiodysplasia is challenging due to difficult accessibility (particularly for small bowel angiodysplasia) and the requirement of active bleeding at the time of examination to identify the lesion (35). Furthermore, angiodysplasia has often multiple locations $(34,35)$.

For cecum and colon, direct endoscopic visualization of the lesion is the standard method of diagnosis (34), while for small bowel lesions video capsule endoscopy appears to be the most appropriate method to detect angiodysplasia, while angiography is frequently a late diagnostic procedure (35). It is worth to mention that both video capsule endoscopy and 
angiography have high successful diagnostic rates only when there is an active bleeding, and for these situations, angiographic embolization of the specific lesions can stop the bleeding (35), as it was the case in our patient. Presence of vascular tufts at visceral angiography in the arterial phase along with early opacification of draining veins suggests the diagnosis of angiodysplasia (34).

Recurrent gastrointestinal bleeding is a common clinical situation in patients with von Willebrand disease, and the commonest cause is angiodysplasia (38\% of patients with gastrointestinal bleeding)(35). Thus, angiodysplasia has increased frequency rates in patients with von Willebrand disease, but the diagnosis and management are challenging. Pathogenesis of angiodysplasia in patients with von Willebrand disease remains unclear (35), as it is the case for most patients with angiodysplasia (34).

The management of angiodysplasia is controversial (34). Furthermore, bleeding stops spontaneously in $90 \%$ of patients, but recurrence rate is high (34). In only $15 \%$ of patients with angiodysplasia, there is a massive digestive bleeding (34). For active bleeding in areas not amenable to endoscopic treatment, interventional radiologic approach (i.e., embolisation of the lesion with coils or gelatin beads) is the best therapy, with morbidity rates (34).

To the best of our knowledge, no association of angiodysplasia with hemophilia A was previously reported. In our patient, there were two locations of angiodysplasia (cecum and jejunum) that presented active bleeding and complicated the postoperative outcome after gastrectomy for gastric cancer. Fortunately, both times the bleeding was stopped with coils insertion with an interventional radiologic approach.

\section{Conclusion}

To the best of our knowledge, this is the first reported association of gastric adenocarcinoma, hemophilia A and angiodysplasia. All these lesions may lead to digestive hemorrhage and can pose very difficult problems of decision for diagnosis and therapy. A multidisciplinary approach including hematologist, surgeon, anesthesiologist, endoscopist and the interventional radiologist is mandatory to have a proper diagnosis and management for these patients.

\section{Acknowledgements}

The paper was presented at the Romanian Society of Surgery Meeting in Bucharest (December 14th, 2017).

\section{Conflict of Interest}

The authors declare no conflicts of interests.

\section{References}

1. Ferro A, Peleteiro B, Malvezzi M, Bosetti C, Bertuccio P, Levi F, et al. Worldwide trends in gastric cancer mortality (1980-2011), with predictions to 2015, and incidence by subtype. Eur J Cancer 2014; 50(7):1330-44.

2. Japanese Gastric Cancer Association. Japanese Classification of Gastric Carcinoma - 2nd English Edition- Gastric Cancer 1998; 1(1):10-24.

3. Vasilescu C, Herlea V, Tidor S, Ivanov B, Stanciulea O, Manuc M, et al. D2 lymph node dissection in gastric cancer surgery: long term results--analysis of an experience with 227 patients. Chirurgia (Bucur) 2006;101(4):375-84.

4. Charalampakis N, Xiao L, Lin Q, Elimova E, Shimodaira Y, Harada K, et al. Co-morbidities Rather than Age Impact Outcomes in Patients Receiving Preoperative Therapy for Gastroesophageal Adenocarcinoma. Ann Surg Oncol 2017;24(8):2291-301.

5. Rausei S, Ruspi L, Rosa F, Morgagni P, Marrelli D, Cossu A, et al. Extended lymphadenectomy in elderly and/or highly co-morbid gastric cancer patients: A retrospective multicenter study. Eur J Surg Oncol 2016;42(12):1881-9.

6. Wilkins T, Khan N, Nabh A, Schade RR. Diagnosis and management of upper gastrointestinal bleeding. Am Fam Physician 2012;85(5): 469-76.

7. Pucheanu X, Beuran M. Can the Principles of Oncological Surgery be Complied with in Haemorrhagic Gastric Cancer? Chirurgia (Bucur) 2015;110(2):123-8.

8. Vasas P, Wiggins T, Chaudry A, Bryant C, Hughes FS. Emergency presentation of the gastric cancer; prognosis and implications for service planning. World J Emerg Surg 2012;7(1):31.

9. Markar SR, Mackenzie H, Jemal S, Faiz O, Cunningham D, Hanna GB. Emergency Presentation of Esophagogastric Cancer: Predictors and Long-term Prognosis. Ann Surg 2017 Mar 20. doi: 10.1097/ SLA.0000000000002224. [Epub ahead of print]

10. Chang JM, Lara KA, Gray RJ, Pockaj BA, Wasif N. Clinical Outcomes after Surgery for Linitis Plastica of the Stomach: Analysis of a Population Cancer Registry. Am Surg 2017;83(1):23-9.

11. Blackham AU, Swords DS, Levine EA, Fino NF, Squires MH, Poultsides G, et al. Is Linitis Plastica a Contraindication for Surgical Resection: A Multi-Institution Study of the U.S. Gastric Cancer Collaborative. Ann Surg Oncol 2016;23(4):1203-11.

12. Jung K, Park MI, Kim SE, Park SJ. Borrmann Type 4 Advanced Gastric Cancer: Focus on the Development of Scirrhous Gastric Cancer. Clin Endosc 2016;49(4):336-45. 
13. Burgain C, Germain A, Bastien C, Orry X, Chone L, Claudon M, et al Computed tomography features of gastrointestinal linitis plastica: spectrum of findings in early and delayed phase imaging. Abdom Radiol (NY) 2016;41(7):1370-7.

14. Kodera Y, Yamamura Y, Shimizu Y, Torii A, Hirai T, Yasui K, et al Peritoneal washing cytology: prognostic value of positive findings in patients with gastric carcinoma undergoing a potentially curative resection. J Surg Oncol 1999;72(2):60-4.

15. Spicer J, Benay C, Lee L, Rousseau M, Andalib A, Kushner Y, et al Diagnostic accuracy and utility of intraoperative microscopic margin analysis of gastric and esophageal adenocarcinoma. Ann Surg Oncol 2014;21(8):2580-6.

16. Younes M. Frozen section of the gastrointestinal tract, appendix, and peritoneum. Arch Pathol Lab Med 2005;129(12):1558-64.

17. Monig SP, Luebke T, Soheili A, Landsberg S, Dienes HP, Holscher AH, et al. Rapid immunohistochemical detection of tumor cells in gastric carcinoma. Oncol Rep 2006;16(5):1143-7.

18. Benevolo M, Mottolese M, Cosimelli M, Tedesco M, Giannarelli D, Vasselli S, et al. Diagnostic and prognostic value of peritoneal immunocytology in gastric cancer. J Clin Oncol 1998;16(10):3406-11.

19. Salen P, Babiker HM. Hemophilia A. StatPearls Publishing, Treasure Island (FL), 2017.

20. Kouides PA, Fogarty PF. How do we treat: upper gastrointestinal bleeding in adults with haemophilia. Haemophilia 2010;16(2):360-2.

21. Berntorp E, Mauser-Bunschoten E, Jimenez-Yuste V, Spears JB. Comorbidities and inhibitors in adult patients with haemophilia: issues, costs and management strategies. Eur $\mathrm{J}$ Haemato 2015:95(Suppl 80):1-15.

22. Biron-Andreani C, de MP, D'oiron R, Chambost H, Schved JF, Hermans C. Cancer detection and management in patients with haemophilia: a retrospective European multicentre study. Haemophilia 2014;20(1):78-82.

23. Huang YC, Tsan YT, Chan WC, Wang JD, Chu WM, Fu YC, et al Incidence and survival of cancers among 1,054 hemophilia patients: A nationwide and 14-year cohort study. Am J Hematol 2015;90(4):E55-E59.

24. Liu CJ, Yu YB, Teng CJ, Hung YP, Hu YW, Hong YC, et al. Increased cancer risk in patients with haemophilia $A$ : a nationwide populationbased 14-year study in Taiwan. Haemophilia 2014;20(6):741-6.
25. Ishikawa M, Suzuki S, Akutu Y, Toyota T, Nose M, Sakai H, et al. An autopsy case of AIDS with hemophilia A who died of DIC and gastrointestinal bleeding associated with gastric carcinoma (signet ring cell carcinoma). Rinsho Ketsueki 1994;35(9):886-91.

26. Rocino A, Carola A, Papa ML, Parisi V, Cremona F, Miraglia E, et al. Major surgery for a gastric cancer in a haemophilic with high inhibitor titre successfully performed by the use of recombinant FVIla. Haemophilia 1999;5(6):441-4.

27. Szczepanik AB, Wislawski S, Windyga J, Huszcza S, Bilski R, Meissner AJ. Strategy for secure hemostasis in hemophilia patients undergoing surgery for malignant neoplasms. Pol Merkur Lekarski 2009;27(161):375-80.

28. Napolitano M, Siragusa S, Mancuso S, Kessler CM. Acquired haemophilia in cancer: A systematic and critical literature review. Haemophilia 2017 Sep 27. doi: 10.1111/hae.13355. [Epub ahead of print]

29. Ljung RCR. How I manage patients with inherited haemophilia A and $\mathrm{B}$ and factor inhibitors. Br J Haematol 2017 Dec 22. doi: 10.1111/bjh.15053. [Epub ahead of print]

30. Harada Y, Iwai M, Miyoshi M, Ueda Y, Mitsufuji S, Seiki K, et al. Lifethreatening hemorrhage in a patient with gastric cancer and acquired hemophilia. Am J Gastroenterol 1998;93(8):1372-3.

31. Hayashi T, Morishita E, Asakura H, Nakao S. Two cases of acquired hemophilia A in elderly patients. Nihon Ronen Igakkai Zasshi 2010; 47(4):329-33

32. Sato K, Tsukada N, Inamura J, Kon M, Ito S, Hirai K, et al. A case of acquired haemophilia A complicated by peritonitis after distal gastrectomy. Haemophilia 2016;22(5):e469-e471.

33. Suzuki T, Arai A, Koyama T, Oshikawa G, Yamamoto M, Mizuchi D, et al. Ischemic colitis following the treatment of acute hemorrhage in a patient with acquired hemophilia A. Rinsho Ketsueki 2006;47(4): 310-4.

34. Beg S, Ragunath K. Review on gastrointestinal angiodysplasia throughout the gastrointestinal tract. Best Pract Res Clin Gastroenterol 2017;31(1):119-25.

35. Makris M, Federici AB, Mannucci PM, Bolton-Maggs PH, Yee TT, Abshire $T$, et al. The natural history of occult or angiodysplastic gastrointestinal bleeding in von Willebrand disease. Haemophilia 2015;21(3):338-42. 